\title{
Cloning and Characterization of Sweetpotato isoamylase gene (IbIsaI) Isolated from Tuberous Root
}

\author{
Sun-Hyung Kim, Tatsuro Hamada, Matoyasu Otani and Takiko Shimada* \\ Research Institute for Bioresources and Biotechnology, Ishikawa Prefectural University, 1-308 Suematu, Nonoichi, Ishikawa 921-8836, Japan
}

The cDNA clone of the sweetpotato isoamylase gene, encoding starch-debranching enzyme (IbIsal) in sweetpotato (Ipomoea batatas (L.), cv. Kokei 14), was isolated and sequenced. The amino acid sequence of IbIsal is $70 \%$ and $79 \%$ identical to that of AtIsal from Arabidopsis and StIsal from potato, respectively. DNA gel-blot analysis demonstrated that at least two copies IbIsal are present in the sweetpotato genome. IbIsal was found to be strongly expressed in tuberous root. The transcript level of IbIsal in the root of rooted single-leaf cuttings was extremely low during the first 15 to 40 days after planting. The transcript levels continuously increased up to 50 days, at which time the tuberous root was almost completely developed. This indicates that IbIsal may work in concert with AGPase large subunit, GBSSI and SBEII during the primary phase of starch granule formation.

Key Words: sweetpotato (Ipomoea batatas (L.) Lam.), Isoamylase, rooted single-leaf cuttings, starch.

\section{Introduction}

Sweetpotato is one of the most important crops in the world and provides not only staple food but also important industrial raw materials. Its starch is used as food and industrial resources. Starch, the most common form of stored carbon in plants, is composed of two types of $\alpha-1,4$-linked glucan polymers: essentially unbranched amylose and regularly branched amylopectin. Amylopectin is synthesized via three committed enzyme steps: ADP-Glc pyrophosphorylase, which synthesizes sugar nucleotide precursors; starch synthase, which extends the $\alpha$-1,4-linked glucan chains using ADP-Glc; and starch-branching enzyme, which introduces $\alpha-1,6$ branch points to form amylopectin. However, the activity of starch-debranching enzymes, which hydrolyze $\alpha$ 1,6 branches in glucans, is also important for amylopectin synthesis (Hussain et al. 2003, Pan and Nelson 1984).

Early research on the maize sul mutant (Pan and Nelson 1984) implicated a role for debranching enzymes (DBE) in determining the chain length of amylopectin sidechains, one of the two components of starch. This conclusion is recently being corroborated by studies on the same mutant and mutants in other organisms. Biochemical analyses of sul mutants of maize (Rahman et al. 1988, James et al. 1995, Beatty et al. 1999), rice (Nakamura 1996, Nakamura et al. 1996, Nakamura et al. 1997) endosperm and sta 7 mutants of Chlamydomonas (Ball et al. 1996, Mouille et al. 1996) indicated that DBEs are involved in amylopectin biosynthesis. Before these studies, DBEs were considered to be mainly

Communicated by S. Nishimura

Received June 27, 2005. Accepted August 22, 2005.

*Corresponding author (e-mail: shimada@ishikawa-pu.ac.jp) catabolic enzymes active during the degradation of starch, such as seen in germinating seeds (Hussain et al. 2003).

In sweetpotato, various components of sink activity have been identified as more important determinants of yield in addition to the photosynthetic capacity of the foliage (Wilson 1982, Fujise and Tsuno 1967, Hozyo 1977). However, the nature of the tuber sink potential is not clear and the genetic factors regulating the tuber sink potential are still unknown. Development of the sweetpotato storage root coincides with starch accumulation, and the genes that affect the synthesis and modification of starch and related metabolisms may play a central role in the control of storage root development and storage sink strength. Extensive studies on carbohydrate metabolism, at the molecular biology level, have been made using the potato as a model plant (Fernie Willmitzer 2001, Fernie et al. 2002). However, a potato tuber is a modified stem, while the sweetpotato storage organ is a modified root. The documentation of information on the expression of carbohydrate metabolism genes in sweetpotato may provide insight into the mechanisms specific for the starch metabolism in root crops.

We focused on the role of isoamylase-debranching enzymes in starch synthesis in developing sweetpotato tubers, and isolated a cDNA clone that encodes isoamylase, IbIsal. IbIsal is strongly expressed in developing tuberous root that synthesize storage starch, and its activity is positively correlated with sink strength during sweetpotato root development.

\section{Material and Methods}

\section{Plant materials}

Adult plants of sweetpotato (Ipomoea batatas (L.), cv. 
Kokei 14) grown in the field were harvested to analyze IbIsal in different organs and for Southern hybridization.

\section{Isolation of Isoamylase gene from sweetpotato}

We extracted RNA using a modified version of the CTAB method (Kim et al. 2002a).

Conserved sequences in MADS box genes were generated using GENETYX (Software Development Co., Japan). One degenerated primer was designed according to the conserved amino acid sequence SINFVCAHDGFTLADLVTYN (GTITGYGCICAYGAYCGITTYACIYTIGC) in an alignment of the isoamylase sequence (Fig. 1A). First strand cDNA was synthesized from tuberous roots according to the manufacturer's instructions accompanying the SMART RACE cDNA Amplification Kit (Clontech, USA) and amplified with templates of cDNA using a degenerated primer and adaptor primer.

The remaining 5'-sequence of cDNA was obtained by 5 '-RACE with total RNA of developing tuberous roots.

\section{Sonthern hybridization}

The CTAB method (Kim et al. 2002a) revised for extraction of genomic DNA from sweetpotato was used. Genomic DNA (about $10 \mu \mathrm{g}$ ) was restricted with EcoRI, $B a m \mathrm{HI}$ and HindIII, separated on a $0.8 \%$ agarose gel, and transferred onto Hybond- $\mathrm{N}^{+}$nylon membranes (Amersham Pharmacia, USA). Filters were hybridized with isoamylase specific probe labeled using DIG direct labeling reagent (Amersham Pharmacia, USA). Hybridization, washing and detection were performed according to the instruction manual of DIG labelling and detection system with CDP star (Amersham Pharmacia, USA).

\section{$R N A$ extraction and Reverse-Transcriptase (RT)-PCR}

Transcript levels were measured by RT-PCR. Total RNA was isolated from whole plants or root tissues as described by Kim et al. (2002a), and treated extensively with RNase-free DNase I to remove any contaminating genomic DNA. The first-strand cDNA was synthesized using $P f u$ Turbo polymerase (Stratagene, USA) from $2 \mu \mathrm{g}$ of total RNA in a $20-\mu l$ reaction volume, and $2 \mu \mathrm{l}$ of the reaction mixture was subjected to subsequent PCR in a $50 \mu$ l reaction volume. IbIsal ( $5^{\prime}$ gtggccaggagggagagttt $3^{\prime}$ and $5^{\prime}$ ccac cgataaccacctcgttc $\left.3^{\prime}\right)$, AGPase large subunit (ADP-glucose pyrophosphorylase large subunit/Genbank accession number AJ252316) (5' cggggatgaagtggtttcaggg $3^{\prime}$ and 5' gggacttt tccatctgccagaagcg $\left.3^{\prime}\right)$ and Tublin ( $5^{\prime}$ caactaccagccaccaactgt $3^{\prime}$ and $5^{\prime}$ caagatcctcacgagcttcac $3^{\prime}$ ) were amplified using the indicated primers according to the following cycling conditions: RT-PCR for 25 or 30 cycles, depending on the linear range of PCR amplification for each gene, with each cycle at $94^{\circ} \mathrm{C}$ for $0.5 \mathrm{~min}, 60^{\circ} \mathrm{C}$ for $0.5 \mathrm{~min}$, and $72^{\circ} \mathrm{C}$ for $1 \mathrm{~min}$, with a final cycle at $72^{\circ} \mathrm{C}$ for $5 \mathrm{~min}$ to allow the completion of polymerization.

\section{DNA sequencing and analysis}

Both strands of the plasmid of positive clones were sequenced using a dye-terminator cycle sequencing kit, and an automated capillary DNA sequencer (Genetic Analyzer ABI 3100, PE Applied Biosystems, U.S.A.). All sequencing data were analyzed using the CLUSTAL-W program (http:// www.ebi.ac.uk/clustalw/). Homology of amino acid sequences was analyzed using CLUSTAL-W program against sequences in the GeneBank and EMBL DNA database. The phylogenetic tree was constructed using the CLUSTAL-W program (http://www.ebi.ac.uk/clustalw/).

\section{Results}

\section{Isolation of sweetpotato Isoamylase (IbIsal)}

Total RNA was isolated from developing tuberous roots of the plants 50 days after planting. This RNA was subjected to RT-PCR using degenerated isoamylase primers, starting with asymmetric amplification on the first strand cDNA (synthesized from the poly A tail) with the degenerated primer of conserved region. Bands between 600-800 bp were subcloned, and found to contain almost exclusively an isoamylase fragment. The remaining 5 '-sequences of the three cDNAs were obtained by $5^{\prime}$-RACE with total RNA of developing tuberous roots. The sweetpotato isoamylase (Genebank accession number DQ074643/IbIsal) full length cDNA was $2510 \mathrm{bp}$ long. The 5- and 3-non-coding regions were 67 and $147 \mathrm{bp}$, respectively. This cDNA was most similar to the potato (StIsal) and Arabidopsis isoamylase (AtIsa1) (Fig. 1A). Southern blot analysis under stringent conditions against sweetpotato genomic DNA revealed over two bands when digested with EcoRI, HindIII and BamHI (Fig. 3). The number of hybridizing bands indicates that the presence of at least two copies of IbIsal in the sweetpotato genome, suggesting that there are more copies of isoamylase in the sweetpotato genome which is a hexaploid plant. It is unclear at present whether this result is due to the hexaploid and heterozygous nature of sweetpotato.

\section{Sequence Analysis of IbIsal}

The deduced amino acid sequences of the Ibisal cDNA suggest that they encode polypeptides of 785 amino acid residues (Fig. 1A). This is within the range of sizes reported for other tuber crop sequences: 793residues in potato isoamylase (Hussain et al. 2003), 783in Arabidopsis isoamylase (Gene accession number At2g39930). The primary structures of Ibisal were aligned with those of other isoamylases in the isoamylase family (Fig. 1A). All isoamylase members share a high degree of amino acid identity $(92 \%-94 \%)$ in the central portion of their amino acid sequences. The amino acid sequence of IbIsal is $70 \%$ and $79 \%$ identical to that of AtIsal from Arabidopsis and StIsal from potato, respectively. Apart from a few stretches of sequence identity and similarity, the $\mathrm{N}$ termini of the isoamylase sequences are divergent (Fig. 1A).

An alignment of the predicted amino acid sequences 
A

IbIsa1 MELLHSPSISQYSPKLHSRSSNIRKTGLSFGFPHNYFAEFEKKARPSALAVNAAIDGGG- 59

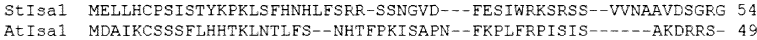

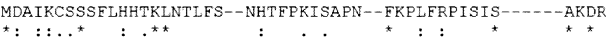

IbIsa1 ----ESDTAVVVEKPLPYGLIRRFEVLSGHPAPFGATARDGGINFAVFSSNATSAALCLI 115 StIsa1 GVVKTAATAVVVEKPT--TERCRFEVLSGKPLPFGATATDGGVNFAVFSRNATAATLCLI 112 AtIsa1 - - NEAENIAVVEKPLK---SDRFFISDGLPSPFGPTVRDDGVNFSVYSTNSVSATICLI 103

IbIsa1 SLADLPEKKVTEQIPLDPS INKTGDVWHVFLQGDFDNMLYGYSFDGKFAPEEGHYFDSAR 175 StIsa1 TLSDLPEKRVTEQIFLDPLANKTGDVWHVFLKGDFENMLYGYKFDGKFCPEEGHYFDSSQ 172

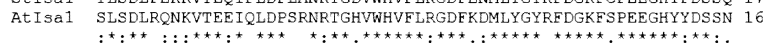

IbIsal ILIDPYAKAIVSRAEFGALGPEKDCWPPMACMLPTA-DKFDWEGDLPLKFPQRDLVIYEM 234 StIsa1 IVLDPYARAIVSRGEYGVLGPEDDCWPMAGMVSASDQFDEGDLPLKFPQRDLVIYEM 232 AtIsa ILLDPYAKAIISRDEFGVLGPDDNCWPQMACMVPTREEEFDWEGDMHLKLPQKDLVIYEM

IbIsa1 HVRGFTNHESSGTEFPGTYRGVVEKLDHLKVLGVNCIELMPCHEFNELEYYSYNPVLGDY 29 StI $s$ 1 HVRGETNHESSETKYPGTYLGVVEKLDHLKELGVNCIELMPCHEFNELEYYSYNSVLGDY 29 At Isa1 HVRGFTRHESSKIEFPGTYQGVAEKLDHLKELGINCIELMPCHEENELEYYSYNT ILGDH 283

IbIsa1 KVNFWGYSTVNFFSPMGRYSSAGMHKSGLGAIDEFKYLVREAHRRGIEVIMDVVFNHTAE 354 At Isa1 RVNFWGYSTIGFFSPMIRYASASSNNFAGRAINEFKILVKEAHKRGIEVIMDVVLNHTAE 34 RVNFWGYSTIGFFSPMIRYASASSNNFAGRAINEFKILVKEAHKRGIEVIMDVVLNHTAE 343 $\begin{array}{ll}\text { IbIsa1 GNENGPMFSFRGVDNSVFYMLAPKGEFYNYSGCGNTFNCNHPVARQFILEFLRYWVIEMH } & 414 \\ \text { StIsal GNENGPILSFRGIDNSVFYTLAPKGEFYNYSGCGNTFNCNNPIVRQFIVDCLRYWVTEMH } & 412\end{array}$ AtIsa1 GNEKGPIFSFRGVDNSVYYMLAPKGEFYNYSGCGNTFNCNHPVVRQFILDCLRYWVTEMH 403

IbIsa1 VDGFRFDLASILTR--_-_-_--_---VAGDMLTTGAPLSSPPLIDMISSDPILSGVKE 460

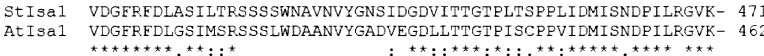

IbIsa1 LIAEAWDCGGLYQVGAFPHWGIWSEWNGKYRDIVRQF IKGTDGESGAFAECLCGSPNLYQ 52 StIsa1 LIAEAWDCGGLYQVGMF PHWGIWSEWNGKYRDMVRQE KGTDGFSGAFAECLCGSPNLY 531 DDVVRQFIKGTDGFSGAFAECLCGSPNLYQ 52

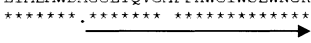

IbIsa1 EGGRKPWNSTINFVAHDGFTLADLVTYNDKHNMANGEDNKDENHNNSWNCGQEGGFASI 58 StIsa1 KGGRKPWNSINFVCAHDGFTLADLVTYNNGHNLANGEDNKDGENHNNSWNCGEEGEFASI 59 AtIsa1 -GGRKPWF INFICAHDGFTLADIVTYNA YNNLANGENNDGENHNYSWNGEEGDFASI 581

IbIsal SVKKLRKRQMRNFFLCLMVSQGVPMIYMGDEYGHTKGGNNNTYCHDNY INYFRWDKKDES 640 AtIsa1 SVKRLRKRQMRNFF

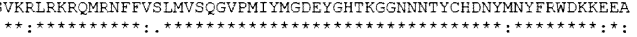

IbIsal STDFFRFCCHVTKFRHEAESLGLDDFPTAERLQWHGHTPGMPDWSESSRFVAFTLVDKVK 700 StIsa1 SSDFLRFCGLMTKFRHECESLGLDGFPTAERLQWHGHTPRTPDWSETSRFVAFTLVDKVK 711 tIsa1 HSDFFRFCRILIKFRDECESLGLNDFPTAKRLQWHGLAPEI PNWSETSRFVAFSLVDSVK 70

Isa1 GEIYIAFNASHLPVTVTLFERGGYRWEPLVDTGKQTPFDFLGDDVPEKKTALKQYAHFLD 760 StIsa1 GELYIAFNASHLPVTITLPDRPGYRWQPFVDTGKPAPFDFLTDDVPERETAAKQYSHFLD 771 EIYVAFNTSHLATLVSLPNRPGYRNEPFVDTSKPSPYDCITPDLPERETAMRQYRHFLD ANMYPMLSYSSIILLLCPDEMIENS 785 ANQYPMLSYSSIILLLSSADDA--- 793

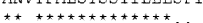

B

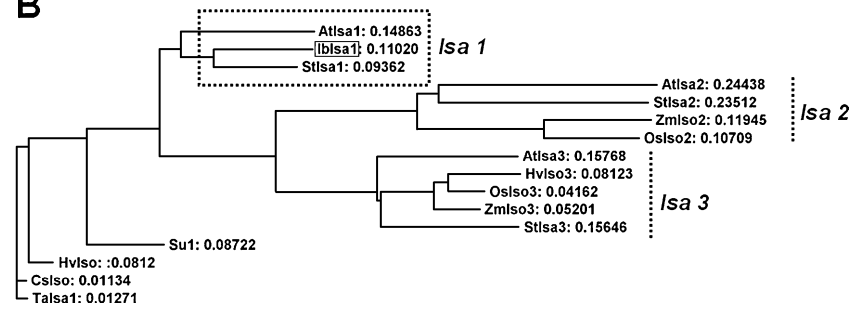

c

Iblsa1 At/sa1 Atlsa2 Atlsa3 Hvlsa Hvlsa3 St/sa1 Stlsa2 Stlsa3 Su1

\begin{tabular}{cccccccccccc}
\hline Iblsa1 & 100 & & & & & & & & & \\
At/sa1 & 70 & 100 & & & & & & & & \\
Atlsa2 & 26 & 26 & 100 & & & & & & & \\
Atlsa3 & 44 & 42 & 31 & 100 & & & & & & \\
Hvlsa & 65 & 65 & 26 & 41 & 100 & & & & & \\
Hvlsa3 & 43 & 42 & 30 & 67 & 43 & 100 & & & & \\
StIsa1 & 79 & 72 & 28 & 44 & 66 & 43 & 100 & & & \\
Stlsa2 & 29 & 28 & 52 & 31 & 29 & 29 & 28 & 100 & & \\
Stlsa3 & 42 & 42 & 29 & 67 & 41 & 66 & 44 & 29 & 100 & \\
Su1 & 66 & 65 & 26 & 42 & 81 & 43 & 68 & 27 & 42 & 100
\end{tabular}

of IbIsal obtained using CLUSTAL W was used to search the Homologous Structure Alignment Database (Mizuguchi et al. 1997) using FUGUE (Shi et al. 2001). The top hit was the catalytic domain of isoamylase from Pseudomonas amyloderamosa (residues 163 to 591) (Katsuya et al. 1998), with clear structural homology $(Z$ score $=57.32$, with $Z$ score $\geq 6.0$ signifying $\geq 99 \%$ confidence). This result is consistent with the conformation of the IbIsal to the structural requirements of members of the $\alpha$-amylase superfamily of $(\alpha \beta)_{8}$ barrel proteins (Fig. 2). IbIsal contained eight regions of $\beta$-strand, each followed by the regions of $\alpha$-helix. Between $\beta$-strand 3 and 4 and between $\beta$-strands 6 and 7 , there were additional regions of $\alpha$-helix in each protein, as has been reported in other starch hydrolases of the $\alpha$ amylase superfamily (Matsuura et al. 1984, Buisson et al. 1987, Jespersen et al. 1993, Klein et al. 1992).

The predicted peptide sequence for IbIsal was used to screen the sequence databases for homologous sequences from other plants. IbIsal is most similar to Atisal from Arabidopsis and the StIsal gene product from potato. These align most closely with IbIsal, Stisal and Atisal, showing that all of these proteins belong to the Isal subgroup of isoamylases in plants which fits well with the similarities in gene expression patterns of IbIsal and StIsal (Fig. 1B). These alignments of the isoform types are present in both monocots and dicots and they fall into structurally distinct isoform classes (Fig. 1B).

\section{Expression patterns of IbIsa 1}

Total RNA was isolated from leaf, petiole, stem, and root tissues, and analyzed with the Ibisal specific primer. To determine the local expression pattern of IbIsal, we examined the expression of the gene in RNA from each organ. RT-PCR revealed that each gene is expressed in petiole, stem, leaf and tuberous root, but only weakly in in white fibrous root and thick pigmented root (Fig. 4A). Hussain et al. (2003) reported that the isoamylase in potato was expressed in both tubers and leaves. This result agrees with our finding

Fig. 1. Phylogenetic relationship among isoamylase isoforms. A. Alignment of fragments of peptide sequences of isoamylases. Degenerated primer site is shown by dashes and box. B. Distance between deduced amino acid sequences of plant isoamylase isoforms determined by the CLUSTAL W program (http:// www.ebi.ac.uk/clustalw/) C. Dendrogram representation of the prediction in $\mathrm{B}$. The dendrogram was generated by the programs CLUSTAL-W program (http://www.ebi.ac.uk/clustalw/). StIsa1, StIsa2 and StIsa3 from potato are AY132996, AY132997 and AY132998, respectively. AtIsal is At2g39930, AtIsa2 is Atlg03310, and AtIsa3 is At4g09020 from Arabidopsis. Taisal is AF438328 from wheat. Hviso (AF142589) and Hviso3 (BAD89532) are an isoamylase identified from barley, SU1 is the product of the sugaryl gene (U18908), and ZmIso2 (AAO17048) and ZmIso3 (AAO17049) from maize, and Osiso2 and Osiso3 are isoamylases from rice (AAT93894 and XP 450961). CrIso is deduced from EST AV630278 from Chlamydomonas. 


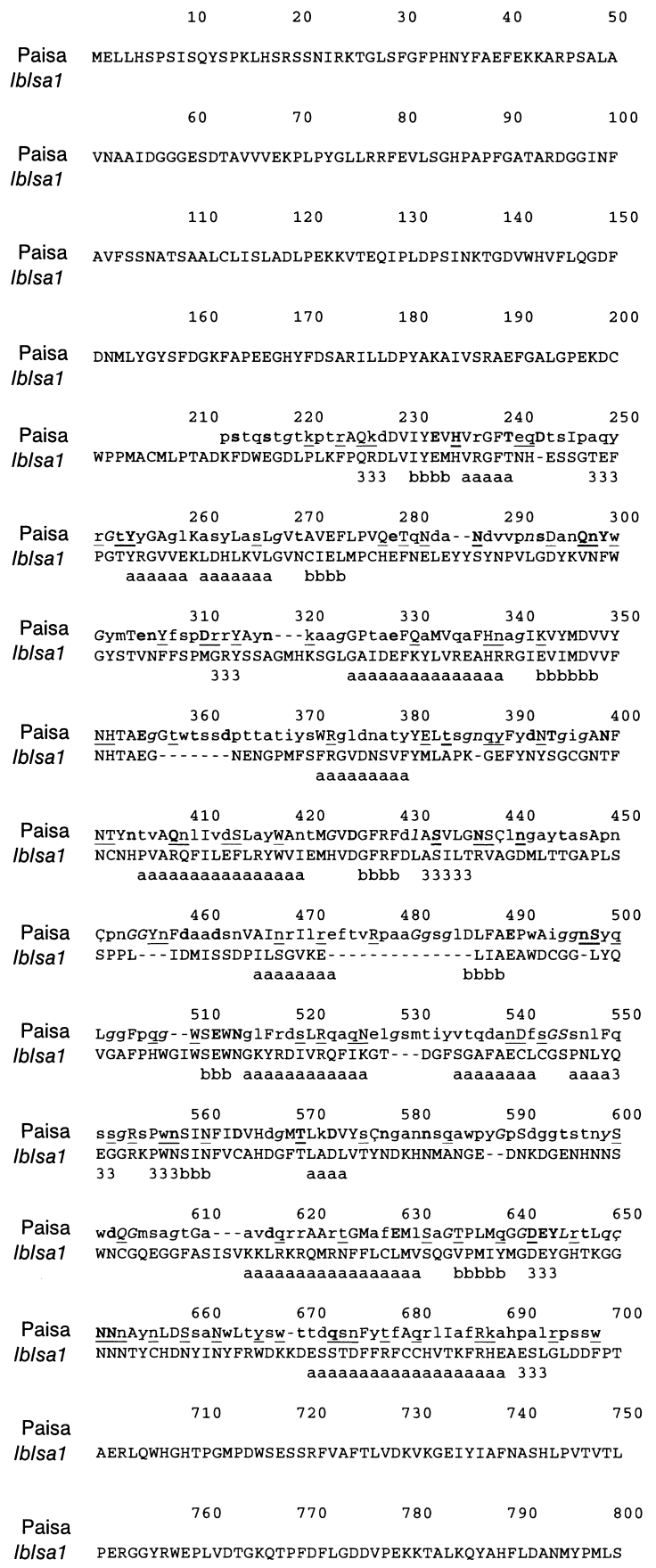

Fig. 2. Alignment of the predicted protein sequences of IbIsal with the isoamylase from $P$. amyloderamosa. Protein sequences were aligned using CLUSTAL W and FUGUE (http://wwwcryst.bioc.cam.ac.uk/ fugue/). Regions of $\beta$-strand in P. amyloderamosa isoamylase (Paisa) are marked (b) below the alignment, regions of $\alpha$-helix (a) below the alignment, and regions of $3 / 10$ helix by (3) below the alignment.

that IbIsal was expressed in both storage starch- and transitory starch-synthesizing tissues.

To elucidate more precisely the relationship between tuber development and the increased expression and temporal expression, we determined IbIsal expression pattern in root tissues from single rooted leaf method (Kim et al.

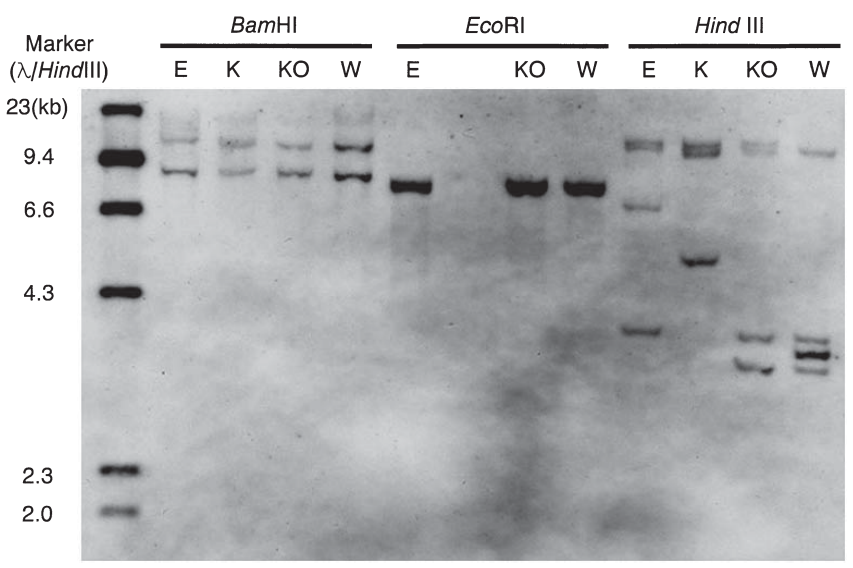

Fig. 3. Southern-blot analysis of genomic DNA from sweetpotato. Genomic DNA (10 $\mu \mathrm{g}$ per lane) of Elegant summer (E), Koganesengan (K), Kokei $14(\mathrm{KO})$ and White star (W) was digested with EcoRI, HindIII and BamHI, fractionated on a $1 \%$ (w/v) agarose gel, and transferred to a nylon membrane. The membrane was hybridized with DIG-labelled IbIsol-specfic probe containing EcoRI digested fragments spanning about 230 amino acid of the C-terminus plus the $3^{\prime}$ untranslated region. The size of marker fragments of DNA is indicated in $\mathrm{kb}$.
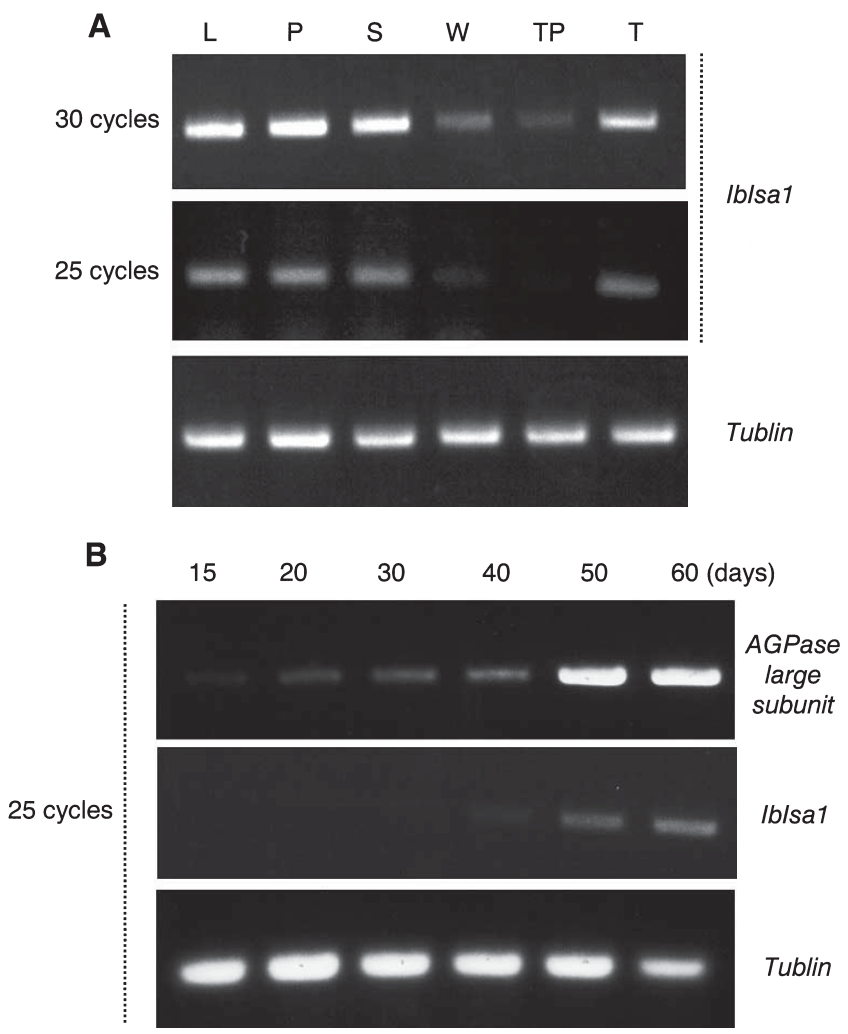

Fig. 4. RT-PCR analysis of the IbIsal gene activity in sweetpotato plants. Total RNA was isolated and used for RT-PCR analysis with gene specific primers as indicated for IbIsal and AGPase large subunit. A. Each organ of sweetpotato at 5 months after planting. L, leaf; P, petiole; S, stem; W, white fibrous root; TP, thick pigmented root; T, tuberous root. B. Sweetpotato roots harvested at the indicated days after planting. Tublin was used as a control. 
2002b). Sweetpotato AGPase large subunit (ADP-Glc pyrophosphorylase) (Bae and Liu 1997, Kim et al. 2002c), was used as references. Interestingly, the IbIsal transcript levels were exceedingly low during the first 20 days to 40 days. The transcript levels continuously increased up to 50 days, at which time the tuberous root was almost completely developed. The temporal expression pattern of the IbIsal was exactly coincided to that of the AGPase large subunit. The expression pattern is similar to that of SBEI (Starch Branching Enzyme I) (unpublished data). Thus, the tissue specificity and temporal expression of IbIsal during root development are similar to that previously reported for the GBSSI (Granule-bound Starch Synthase I), SBEII (Starch Branching Enzyme II) (Kim et al. 2005) and in concert during the stages of starch granule formation,

\section{Discussion}

cDNA clones encoding isoamylase-type starchdebranching enzyme (IbIsal) were isolated from sweetpotato. The predicted products of IbIsal are similar to other plant isoamylases, and the proteins belong to the $\alpha$-amylase superfamily. Genes that encode isoamylase also can be identified Arabidopsis and potato (Goff et al. 2002, Yu et al. 2002, Hussain et al. 2003). By phylogenetic analysis, we found that IbIsal is highly homologous to that StIsal from potato and AtIsal from Arabidopsis. We classified IbIsal protein as a new gene of Isal subgroup. After searching the Genebank from different higher plants, we found that IbIsal is produced in most, if not all, monocots and dicots and that they represent the major types of isoamylase produced in angiosperms.

Structural analysis revealed that IbIsal was highly similar to the $S u l$ protein of maize that is associated with sugary phenotypes when mutated and to other isoamylases from potato. Mutants of sugaryl of maize, sugary of rice, and notch 2 of barley have reduced storage starch synthesis in endosperm and accumulate a highly branched, water-soluble polysaccharide, phytoglycogen (Pan and Nelson 1984, Burton et al. 2002). We compared the primary amino acid sequences of the IbIsal with those of isoamylase from P. amyloderamosa (Fig. 2). Differences in loop lengths between $\beta$-strands and $\alpha$-helices provide specificity for substrate binding in different members of the $(\alpha \beta)_{8}$ barrel starch hydrolase superfamily (MacGregor 1993).

The results of RT-PCR revealed high activity of the IbIsal gene in tuberous roots. However, the IbIsal gene was poorly expressed in the white fibrous root and thick pigmented root (Fig. 4A). These findings indicate that the main role of isoamylase is the starch formation in the sink tissues during sweetpotato root development. However, expression of the IbIsal gene was also detected in leaf, petiole, and stem tissues (Fig. 4A). Whether isoamylase in sink organs has a function or activity different from that in source tissues in sweetpotato remains unknown. Are there other isoforms of isoamylase in sweetpotato? Two types of isoamylases (with a molecular mass of 68 and $140 \mathrm{kDa}$ ) were purified from developing maize kernels (Doehlert and Knutson 1991 ) and one type (with a monomeric molecular mass of $80-95 \mathrm{kDa}$ ) from potato tubers (Ishizaki et al. 1983). Southern hybridization suggested the presence of at least two copies of IbIsal in Kokei 14. The band patterns in HindIII digestion within different cultivars (Koganesengan, White star and Elegant summer) (Fig. 3) are different. It is unclear at present whether this result is due to the hexaploid and heterozygous nature of sweetpotato. However, it would be interesting to clarify the homology between these copies of IbIsal and whether they have the same strength and expression pattern.

AGPase large subunit is a key enzyme for starch synthesis and is a marker of tuberization in sweetpotato, which means that the AGPase large subunit is positively correlated with sink strength under normal conditions (Kim et al. 2002c). Expression of the AGPase large subunit expression in sweetpotato root started at the initial stage of tuberization reaching a maximum at day 50 , consistent with the report of Kim et al. (2002c). As shown in Fig. 4 B, expression of the AGPase large subunit increased with time after planting. On the other hand, expression of SBEI (Starch Branching Enzyme I), SBEII (Starch Branching Enzyme II) and GBSSI (Granule-bound Starch Synthase I) was low during the initial 30-40 days after planting and increased at day 50 (Kim et al. 2005). These results suggest that IbIsal works in concert with AGPase large subunit, GBSSI, SBEI and SBEII during the primary phase of starch granule formation.

In the present work, we isolated the IbIsal gene and demonstrated that the synthesis and expression pattern of the gene during root development were similar to those of isoamylase. Further studies on the regulation of IbIsal expression in developing tuberous root in transgenic plants are needed.

\section{Acknowledgements}

We wish to thank Megumi Fujita for technical assistance.

\section{Literature Cited}

Bae,J.M. and J.R.Liu (1997) Molecular cloning and characterization of two novel isoforms of the small subunit of ADPglucose pyrophosphorylase from sweetpotato. Mol. Gen. Genet. 254: 179-185.

Ball, S., H.-P.Guan, M.James, A.Myers, P.Keeling, G. Mouille, A. Buléon, P.Colonna and J.Preiss (1996) From glycogen to amylopectin: a model for the biogenesis of the plant starch granule. Cell 86: 349-352.

Beatty,M.K., A.Rahman, H.Cao, W.Woodman, M.Lee, A.M.Myers and M.G.James (1999) Purification and molecular genetic characterization of $Z P U 1$, a pullulanase-type starch-debranching enzyme from maize. Plant Physiol. 119: 255-266.

Buisson,G., E.Duée, R.Haser and F.Payan (1987) Three dimensional structure of porcine pancreatic alpha-amylase at $2.9 \AA$ resolu- 
tion: Role of calcium in structure and activity. EMBO J. 6 : 3909-3916.

Burton, R., H.Jenner, L. Carrangis, B.Fahy, G. Fincher, C. Hylton, D.Laurie, M.Parker, D.Waite, S.van Wegen, T.Verhoeven and K.Denyer (2002) Starch granule initiation and growth are altered in barley mutants that lack isoamylase activity. Plant $\mathrm{J}$. 31: 97-112.

Doehlert,D.C. and C.A.Knutson (1991) Two classes of starch debranching enzymes from developng maize kernels. J. Plant Physiol. 138: 566-572.

Fernie,A.R. and L.Willmitzer (2001) Molecular and biochemical triggers of potato tuber development. Plant Physiol. 127: 14591465.

Fernie,A.R., L. Willmitzer and R.N. Trethewey (2002) Sucrose to starch: a transition in molecular plant physiology. Trends Plant Sci. 7: 35-41.

Fujise,K. and Y.Tsuno (1967) The effect of potassium on dry matter production of sweetpotato. In "Proceeding of the International Symposium on Tropical Root Crops, Vol. 1." Univ. of the West Indies, Trinidad. pp. 20-33.

Goff, S.A., D. Ricke, T.H.Lan, G.Presting, R.Wang et al. (2002) A draft sequence of the rice genome (Oryza sativa L. ssp japonica). Science 296: 92-100.

Hozyo,Y. (1977) The influences of source and sink on plant production of Ipomoea grafts. Jpn. Agri. Res. Quarterly 11: 77-83.

Hussain,H., A.Mant, R.Seale, S.Zeeman, E.Hinchliffe, A.Edwards, C.Hylton, S.Bornemann, A.M.Smith, C.Martin and R.Bustos (2003) Three isoforms of isoamylase contribute different catalytic properties for the debranching of potato glucans. Plant Cell 15: 133-149.

Ishizaki,Y., H.Taniguchi, Y.Maruyama and M.Nakamura (1983) Debranching enzymes of potato tubers (Solanum tuberosum L.). I. Purification and some properties of potato isoamylase. Agric. Biol. Chem. 47: 771-779.

James, M.G., D.S.Robertson and A.M.Myers (1995) Characterization of the maize gene sugary-1, a determinant of starch composition in kernels. Plant Cell 7: 417-429.

Jespersen,H.M., E.A.MacGregor, B.Henrissat, M.R.Sierks and B. Svenson (1993) Starch- and glycogen-debranching and branching enzymes: Prediction of structural features of the catalytic $(\alpha \beta)_{8}$-barrel domain and evolutionary relationship to other amylolytic enzymes. J. Protein Chem. 12: 791-805.

Katsuya, Y., Y.Mezaki, M.Kubota and Y.Matsuura (1998) Threedimensional structure of Pseudomonas isoamylase at $2.2 \AA$ resolution. J. Mol. Biol. 281: 885-897.

Kim,S.H., K.Mizuno and T.Fujimura (2002a) Isolation of MADS-box genes from sweetpotato (Ipomoea batatas (L.) Lam.) expressed specifically in vegetative tissues. Plant and Cell Physiol. 43: 314-322.

Kim,S.H., K.Mizuno and T.Fujimura (2002b) Regulated expression of ADPglucose pyrophosphorylase and chalcone synthase during root development in sweetpotato. Plant Growth Regul. 38: 173-189.
Kim, S.H., K.Mizuno, S. Sawada and T. Fujimura (2002c) Regulation of tuber formation and ADP-glucose pyrophosphorylase (AGPase) in sweetpotato (Ipomoea batatas (L.) Lam.) by nitrate. Plant Growth Regul. 37: 207-213.

Kim,S.H., T.Hamada, M.Otani, H.Koga and T.Shimada (2005) Use of single-leaf cutting in the study of the expression of starch synthesis and modification genes in sweetpotato. J. Plant Biotech. 7: $123-127$

Klein,C., J.Hollender, H.Bender and G.E.Schulz (1992) Catalytic center of cyclodextrin glycosyltransferase derived from X-ray structure-analysis combined with site-directed mutagenesis. Biochemistry 31: 8740-8746.

MacGregor,E.A. (1993) Relationships between structure and activity in the $\alpha$-amylase family of starch-metabolising enzymes. Starch 45: 232-237.

Matsuura,Y., M.Kusunoki, W.Harada and M.Kakudo (1984) Structure and possible catalytic residues of taka-amylase A. J. Biochem. 95: 697-702.

Mizuguchi,K., C.M.Deane, T.L.Blundell and J.P.Overington (1997) HOMSTRAD: A database of protein structure alignments for homologous families. Protein Sci. 7: 2469-2471.

Mouille,G., M.L.Maddelein, N.Libessart, P.Talaga, A.Decq, B.Delrue and S.Ball (1996) Preamylopectin processing: a mandatory step for starch biosynthesis in plants. Plant Cell 8: 1353-1366.

Nakamura,Y. (1996) Some properties of starch debranching enzymes and their poossible role in amylopectin biosynthesis. Plant Sci. 121: 1-18.

Nakamura, Y., T.Umemoto, Y.Takahata, K.Komae, E.Amano and H.Satoh (1996) Changes in structure of starch and enzyme activities affected by sugary mutations in developing rice endosperm. Possible role of starch debranching enzyme in amylopectin biosynthesis. Physiol. Plant. 97: 491-498.

Nakamura, Y., A.Kubo, T.Shimamune, T.Matsuda, K. Harada and H.Satoh (1997) Correlation between activities of starch debranching enzyme and $\alpha$-polyglucan structure in endosperms of sugary-1 mutants of rice. Plant J. 12: 143-153.

Pan,D. and O.E. Nelson (1984) A debranching enzyme deficiency in endosperms of the sugary-1 mutants of maize. Plant Physiol. 74: $324-328$.

Rahman,A., K.S.Wong, J.L.Jane, A.M.Myers and M.G.James (1998) Characterization of SU1 isoamylase, a determinant of storage starch structure in maize. Plant Physiol. 117: 425-435.

Shi,J., T.L.Blundell and K.Mizuguchi (2001) FUGUE: Sequencestructure homology recognition using environment-specific substitution tables and structure-dependent gap penalties. J. Mol. Biol. 310: 243-257.

Wilson,L.A. (1982) Tuberization in sweetpotato (Ipomoea batatas (L). Lam.). In "Sweetpotato", Villareal,R.L. and T.D.Griggs (eds.), Asian Vegetable Research and Development Center, Shanhua, Twainan, Taiwan. pp. 79-94.

Yu,J., S.Hu, J.Wang, G.K.Wong, S.Li et al. (2002) A draft sequence of the rice genome (Oryza sativa L. ssp indica). Science 296: 79-92. 